\title{
PEMANFAATAN LABORATORIUM VIRTUAL DAN E-REFERENCE DALAM PROSES PEMBELAJARAN DAN PENELITIAN ILMU KIMIA
}

\author{
Ratih Rizqi Nirwana
}

\begin{abstract}
Abstrak
Teknologi informasi dan komputer telah berkembang sedemikian pesatnya, dan memiliki pengaruh yang luar biasa. Namun, kedua teknologi tersebut masih kurang pemanfaatannya di dunia pendidikan di Indonesia. Melalui laboratorium virtual proses pembelajaran menjadi lebih menarik, lebih interaktif, jumlah waktu mengajar dapat dikurangi, kualitas belajar dapat ditingkatkan dan proses belajar mengajar dapat dilakukan di mana saja dan kapan saja. Selain itu, melalui laboratorium virtual, bisa dilakukan penghematan biaya riset, serta riset-riset yang dahulu tidak mungkin dilakukan, karena keterbatasan pengkondisian sistem. Sedangkan E-references bisa digunakan bersinergi dalam mengatasi kelemahan laboratorium virtual yaitu kurangnya kemampuan dalam mengatasi masalah.
\end{abstract}

Keywords: laboratorium virtual, e-reference, multimedia 


\section{Pendahuluan}

Teknologi informasi dan komputer telah berkembang sedemikian pesatnya, dan memiliki pengaruh yang luar biasa. Salah satu implikasinya dapat dirasakan dalam perkembangan media pembelajaran yang sekarang sudah berbantuan komputer dan internet. Media pembelajaran ini sering juga disebut multimedia pembelajaran. Multimedia adalah media yang menggabungkan lebih dari 2 unsur media yang terdiri dari teks, grafis (gambar, foto, animasi), suara (audio) dan video secara terintegrasi.

Inovasi terus menerus pada multimedia akhirnya melahirkan suatu laboratorium maya, atau yang sering disebut dengan laboratorium virtual. Saat ini di Negara-negara maju, laboratorium virtual telah mulai banyak digunakan untuk pembelajaran dan juga penelitian. Hal ini tentu saja semakin mempermudah proses pembelajaran dan juga proses riset yang dilakukan.

Seiring pula dengan perkembangan teknologi informasi dan komputer di atas, internet telah berkembang menjadi kebutuhan bagi lebih dari puluhan juta orang di dunia, sebagai konsekuensi dari semakin murahnya biaya yang dibutuhkan bagi teknologi komputasi dan komunikasi. Hal ini turut didukung oleh ketersediaan perangkat lunak yang sangat mudah dioperasionalkan dari waktu ke waktu.

Sayangnya, kedua teknologi tersebut masih kurang pemanfaatannya di dunia pendidikan di Indonesia. Padahal para ilmuwan, termasuk peneliti, dosen dan mahasiswa, guru dan siswa adalah di antara kelompok-kelompok yang sangat diuntungkan.

\section{Laboratorium Virtual}

Laboratorium Virtual bermula dari sebuah proyek yang bernama "Essays and Resources on the Experimentalization of Life (1830-1930) yang berlokasi di Max Planck Institute for the History of Science. Proyek ini bertujuan untuk meneliti sejarah tentang experimentalization of life. Istilah experimentalization menjelaskan interaksi antara ilmu kehidupan, seni, arsitektur, media dan teknologi dalam paradigma eksperimen. Platform 
dari Laboratorium virtual tersebut tidak hanya tentang topic tersebut diatas, melainkan juga berperan sebagai lingkungan penelitian untuk penelitian-penelitian yang baru (Wikipedia, 2010)

Pada tahun 1997, versi pertama dari laboratorium virtual yang diberi nama "Virtual laboratory of Physiology" mulai dipresentasikan. Pada saat itu, focus utama ada pada pengembangan pra-kondisi teknologis dari penellitian-penelitian fisiologis pada abad 19. Untuk itu, sebuah database dengan teks dan gambar yang relevan diciptakan. Pada tahun 19988, konsep yang masih digunakan sampai sekarang diciptakan seteleh melalui beberapa kali modifikasi, dan diikuti oleh publikasi sebuah CD-ROM pada 1999. Pada saat itu, focus telah diperluas dari fisiologi ke ilmu pengetahuan alam secara umum. Pada tahun 2002, versi pertama laboratorium virtual dionlinekan. Sejak 2008, "the Virtual Laboratory" telah terdata sebagai sebuah jurnal dengan nomor ISSN 1866-4784. (Wikipedia, 2010)

Menurut Ensiklopedia Online Gunadharma, istilah Laboratorium Virtual, kini tidak hanya mengacu pada the Virtual Laboratory (Journal). Akan tetapi ini telah menjadi istilah yang menggambarkan proses pembelajaran elektronik dengan menggunakan simulasi komputer. Laboratorium virtual merupakan media yang digunakan untuk membantu memahami suatu pokok bahasan dan dapat mensolusi keterbatasan atau ketiadaan perangkat laboratorium.

Melalui laboratorium virtual, simulasi suatu kondisi yang kompleks, terlalu mahal atau berbahaya, yang kadang tidak dapat dilakukan pada konsisi riil, menjadi dapat dilakukan. Secara financial, membangun sebuah laboratorium virtual juga relatif sangat terjangkau. Laboratorium berbasis komputer ini memungkinkan para siswa atau mahasiswa dapat melakukan praktikum atau eksperimen seolah menghadapi fenomena atau set peralatan laboratorium nyata. Beberapa laboratorium virtual kimia online adalah www.modelscience.com, www.chemcollective.org, oxford (www.chem.ox.ac.uk/vrchemistry), dll

Melalui pembelajaran multimedia dalam bentuk laborato- 
rium virtual, secara umum manfaat yang dapat diperoleh adalah proses pembelajaran menjadi lebih menarik, lebih interaktif, jumlah waktu mengajar dapat dikurangi, kualitas belajar dapat ditingkatkan dan proses belajar mengajar dapat dilakukan di mana saja dan kapan saja. Selain itu, melalui laboratorium virtual, bisa dilakukan penghematan biaya riset, serta riset-riset yang dahulu tidak mungkin dilakukan, karena keterbatasan pengkondisian sistem, saat ini telah bisa dilakukan (Reismeiyanto, 2008).

Menurut Farreira (2010), Beberapa manfaat yang dapat diperoleh dengan menggunakan laboratorium virtual online adalah

1. Mengurangi keterbatasan waktu, jika tidak ada cukup waktu untuk mengajari seluruh peserta didik di dalam lab hingga mereka paham,

2. Mengurangi hambatan geografis, jika terdapat siswa atau mahasiswa yang berlokasi jauh dari pusat pembelajaran (kampus),

3. Ekonomis, tidak membutuhkan bangunan lab, alat-alat dan bahan-bahan seperti pada laboratorium konvensional,

4. Meningkatkan kualitas eksperimen, karena memungkinkan untuk diulang untuk memperjelas keraguan dalam pengukuran di lab,

5. Meningkatkan efektivitas pembelajaran, karena siswa atau mahasiswa akan semakin lama menghabiskan waktunya dalam lab virtual tersebut berulang-ulang,

6. Meningkatkan keamanan dan keselamatan, karena tidak berinteraksi dengan alat dan bahan kimia yang nyata

Menurut peneliti dari Labshare, berikut ini adalah kelebihan dari lab virtual.

1. Meningkatkan dapat diaksesnya laboratorium

2. Menurunkan biaya pengelolalan dan pemeliharaan laboratorium sebesar $50 \%$.

3. Meningkatkan pembelajaran untuk mensupport pembelajaran yang lebih baik. 
4. Memacu untuk pertukaran pengetahuan, keahlian dan pengalaman,

5. Mengurangi biaya untuk membuat laboratorium.

Akan tetapi, selain banyak manfaat yang bisa dipetik dari pemanfaatan lab virtual, ada juga beberapa kelamahannya, diantaranya adalah sebagai berikut.

1. Kurangnya pengalaman untuk menyelesaikan masalah

2. Kurangnya pengalaman untuk merangkai alat

\section{E-Reference}

Istilah e-reference (electronic reference sources) yang sering ditemui saat ini mengacu pada e-book, e-journal, e-library, ensiklopedi online, artikel online, dll. Suatu e-reference merupakan referensi yang bisa diperoleh dalam bentuk digital, dan bisa juga diperoleh secara online melalui internet. Dengan majunya Internet, para ilmuwan bagaikan hidup di sebuah "wonderland" yang penuh keajaiban dan kemungkinan, karena internet menawarkan informasi yang sangat melimpah, yang sangat mereka butuhkan. Hampir semua informasi bisa ditemukan di internet, dan hampir seluruh pertanyaan tersedia jawabannya di internet.

Banyak penelitian yang sedang berjalan ditampilkan juga di internet. Paper seminar, artikel-artikel lepas dan bahkan buku atau bagian-bagian dari buku juga ditampilkan di internet dalam format elektronik. Sebagian besar informasi ini bisa diperoleh secara cuma-cuma. Bagi dunia pendidikan, fenomena ini sangat menarik karena ini bisa menjadi alternatif memperoleh referensi dengan biaya terjangkau bagi pihak-pihak yang melakukan riset ataupun para pendidik dan para peserta didik untuk menunjang pembelajaran.

Akan tetapi, informasi yang sangat melimpah yang tersedia di internet tidak sepenuhnya menguntungkan bagi seorang peneliti karena, dalam banyak kasus, masalah yang dihadapi oleh seorang peneliti bukanlah ketiadaan melainkan terlalu banyaknya informasi atau data yang tersedia. Masalah pemilahan informasi ini menjadi lebih serius dalam riset melalui internet, 
karena internet merupakan sebuah ruang terbuka, siapapun bisa menyebarkan 'informasi' apapun. Konsekuensinya, sekalipun banyak informasi yang sangat berkualitas yang bisa ditemukan di internet, tidak kurang juga informasi yang mungkin lebih tepat dimasukan ke tong sampah.

E-references berbeda dengan digital library. Menurut Hernyaman (2007), berikut ini adalah perbedaannya. E-Library atau perpustakaan digital bersifat umum (untuk semua bidang keilmuan), sehingga diperlukan keterampilan pengguna untuk memanfaatkan materi yang dibutuhkan. Sedangkan e-references, pengguna diarahkan pada pencarian yang telah dikelompokkan pada bidang-bidang keilmuan khusus sehingga lebih memudahkan pengguna dalam pencarian dan pengayaan materi yang dibutuhkan sesuai dengan latar belakang keilmuannya. e-references mengarahkan pengguna pada pilihan-pilihan direktori situs yang relevan.

Berikut ini kategori sumber (categories resources) dalam $e^{-}$ references.

1. Online Journal, free acces full text

2. Hasil Penelitian

3. Research Centers

4. Library Catalogue

5. Organisation (IGOs atau NGOs)

6. Association of Proffesional

7. State and non-state department

8. Perguruan tinggi/ prodi dengan keilmuan tertentu

9. Others (Tergantung Bidang Keilmuan)

Jika dilihat dari banyaknya referensi yang terhimpun dalam e-references, bisa ditarik kesimpulan bahwa manfaat dari e-references adalah

1. Membantu siswa ataupun mahasiswa, Dosen, Peneliti dan Publik yang berminat untuk melakukan Riset melalui Internet

2. Memberikan alternative diluar Riset Perpustakaan Konvensional 
3. Memudahkan pencarian referensi keilmuan dari berbagai sumber (jurnal, hasil penelitian, perkembangan buku teks, website institusi terkait, dll) bagi para mahasiswa dalam menyelesaikan skripsi, tesis, disertasi maupun bagi para dosen dan peneliti dalam melakukan berbagai macam penelitian.

4. Mempercepat keterhubungan (quick search) terhadap jaringan referensi terintegrasi yang sesuai dengan keilmuan yang dibutuhkan melalui media virtual, disbanding mencari referensi secara parsial melalui fasilitas search engine yang umum(Google, Yahoo, Clusty, dll).

5. Menghindari kesulitan dan kesalahan-kesalahan dalam mencari sumber-sumber referensi yang diperlukan melalui media virtual yang pada akhirnya dapat menghindari kerugian dari sisi waktu dan biaya

Berikut ini e-reference yang tersedia secara online, diantaranya www.online.sagepub.com, www.elsevier.com, www. en.wikipedia.com, dll. Sedangkan e-reference dalam bahasa Indonesia diantaranya dimiliki oleh UNPAS.

\section{Sinergi Penggunaan E-Reference dan Laboratorium Virtual dalam Proses Pembelajaran dan Penelitian Ilmu Kimia}

Dunia pendidikan memang perlu merangkul kemajuan teknologi dan informasi, dan mengimbangi percepatan kemajuannya dengan cara terus menerus melakukan inovasi di bidang pendidikan. Salah satu upaya yang bisa dilakukan adalah dengan menciptakan laboratorium virtual dan e-references.

Laboratorium virtual dan e-references jika digunakan secara bersinergi akan bisa melengkapi satu sama lain. E-references bisa mensupport pemikiran kritis yang dihadapi oleh peserta didik ataupun peneliti saat berhadapan dengan laboratorium virtual. Misalnya saja dalam mengatasi kelemahan laboratorium virtual yaitu kurangnya kemampuan dalam mengatasi masalah. Hal ini dapat dibantu dengan adanya e-references. Caranya adalah dengan mencari jawaban atas masalah yang dihadapi melalui $e$ reference. 
Adanya laboratorium virtual dan e-reference juga memudahkan siapapun untuk belajar kapan saja dan di mana saja, dengan biaya yang sangat terjangkau atau bahkan gratis (jika tersedia secara open source di internet). Artinya, kedua teknologi pendidikan tersebut bisa menunjang terbentuknya masyarakat pembelajar (learning society) dan belajar seumur hidup (lifelong learning) yang pastinya akan semakin mencerdaskan kehidupan bangsa.

Salah satu contoh pemanfaatan laboratorium virtual dalam pembelajaran dan riset adalah di dalam ilmu kimia. Berbagai laboratorium virtual yang tersedia secara online menyediakan eksperimen virtual diantaranya yang berkaitan dengan asambasa. Materi ini adalah materi kimia yang dasar, sehingga bisa dimanfaatkan oleh siswa SMA, mahasiswa, hingga para peneliti yang ingin melakukan penelitian yang berkaitan dengan asam dan basa. Setelah melakukan eksperimen, pasti siswa ataupun peneliti membuat laporan eksperimen. Dengan memanfaatkan e-reference yang ada, siswa, mahasiswa, pendidik sampai peneliti bisa memetik manfaat dan kemudahan diperolehnya artikel, laporan penelitian, jurnal, e-book, dll dalam satu atap.

\section{Kesimpulan}

Kemajuan teknologi dan informasi telah mendorong terciptanya laboratorium virtual dan e-references. Melalui keduanya, proses pembelajaran akan semakin mudah dan semakin murah. Akan tetapi, masih sedikit laboratorium virtual dan e-reference yang dimiliki Indonesia. Harapan di masa mendatang, akan banyak diciptakan laboratorium virtual dan e-references di Indonesia yang tersedia secara gratis. Sehingga riset-riset akan semakin maju, proses pendidikan juga semakin menyenangkan, serta semakin terjangkau oleh masyarakat. 


\section{DAFTAR PUSTAKA}

Arahova, A, 2007, “E-reference and E-learning: Collaborative Services under a User - Centered Option", http:/ / archive.ifla.org/ VII/s46/conf/Arahova-2007.pdf

Ensiklopedia Online Universitas Gunadharma, http://www. gunadarma.ac.id/en/-page/virtual-lab.html

Ferreira, Sousa, Nafalski, Machotka, Nedic, 2010. "Collaborative learning based on a micro-webserver remote test controller", Bridgeport, University of South Australia,

Hernyaman, O, 2007, "Pemanfaatan e-references dalam Proses Pembelajaran dan Riset", http://www.scribd.com/ doc/5988373/Pemanfaatan-eReferences-dalam-ProsesPembelajaran-dan-Riset

Resmiyanto, R, 2008, “Telaah Laboratorium Maya Berdasarkan Model Sains Kuhnian dan Implikasinya dalam Pembelajaran Fisika", http://www.scribd.com/doc/26109360/ Rachmad-Resmiyanto-Telaah-Laboratorium-MayaBerdasarkan-Model-Sains-Kuhnian-Dan-ImplikasinyaDalam-Pembelajaran-Fisika

Rohmadi, N, 2010, "Pembelajaran Fisika Menggunakan Lab Virtual", http://www.scribd.com/doc/32702331/makalahpembelajaran-fisika-menggunakan-lab-virtual

Wikipedia, 2010, "Virtual laboratory", http://en.wikipedia.org/ wiki/Virtual-_Laboratory 
Listyono

124 Jurnal PHENOMENON, Volume 1 Nomor 1, Juli 2011 


\section{ORIENTASI LIFE SKIL DALAM KURIKULUM TINGKAT SATUAN PENDIDIKAN DENGAN PENDEKATAN SETS \\ (Science Environment Technology \& Society) PADA JENJANG PENDIDIKAN DASAR \& MENENGAH}

\section{Listyono}

\section{A. Pendahuluan}

Kurikulum Tingkat Satuan Pendidikan (KTSP) adalah sebuah kurikulum operasional pendidikan yang disusun oleh dan dilaksanakan di masing-masing satuan pendidikan di Indonesia. KTSP secara yuridis diamanatkan oleh Undang-Undang Nomor 20 Tahun 2003 tentang Sistem Pendidikan Nasional dan Peraturan Pemerintah Republik Indonesia Nomor 19 Tahun 2005 tentang Standar Nasional Pendidikan. KTSP merupakan bagian yang tidak terpisahkan dari SI, namun pengembangannya diserahkan kepada sekolah agar sesuai dengan kebutuhan sekolah itu sendiri. Basis dari kurikulum ini adalah kompetensi yang harus dikuasai oleh siswa. Kompetensi merupakan pengetahuan, ketrampilan dan nilai-nilai yang direfleksikan dalam kebiasaan berfikir dan bertindak.

Pemberlakuan KTSP, sebagaimana yang ditetapkan dalam peraturan Menteri Pendidikan Nasional No. 24 Tahun 2006 tentang Pelaksanaan SI dan SKL, ditetapkan oleh kepala sekolah setelah memperhatikan pertimbangan dari komite sekolah. Dengan kata lain, pemberlakuan KTSP sepenuhnya diserahkan kepada sekolah, dalam arti tidak ada intervensi dari Dinas Pendidikan atau Departemen Pendidikan Nasional. Penyusunan KTSP selain melibatkan guru dan karyawan juga melibatkan komite sekolah serta bila perlu para ahli dari perguruan tinggi 
setempat. Dengan keterlibatan komite sekolah dalam penyusunan KTSP maka KTSP yang disusun akan sesuai dengan aspirasi masyarakat, situasi dan kondisi lingkungan dan kebutuhan masyarakat.

Kecakapan hidup merupakan orientasi pendidikan yang mensinergikan mata pelajaran menjadi kecakapan yang diperlukan seseorang,dimanapun ia berada,bekerja, atau tidak bekerja.

Kecakapan hidup (Life Skill) yaitu kemampuan dan keberanian untuk menghadapi problema kehidupan, kemudian secara proaktif dan kreatif, mencari serta menemukan solusi untuk mengatasi suatu permasalahan. Pengertian kecakapan hidup lebih luas dari keterampilan vokasional atau keterampilan untuk bekerja. Orang yang tidak bekerja, misalnya ibu rumah tangga atau orang yang sudah pensiun, tetap memerlukan kecakapan hidup. Seperti halnya orang yang bekerja, mereka juga menghadapi berbagai masalah yang harus dipecahkan. Orang yang sedang menempuh pendidikan pun memerlukan kecakapan hidup , karena mereka tentu juga memiliki permasalahannya sendiri.

Dengan bekal kecakapan hidup yang baik, diharapkan para lulusan akan mampu memecahkan problema kehidupan yang dihadapi, termasuk mencari atau menciptakan pekerjaan bagi mereka yang tidak melanjutkan pendidikannya. Untuk mewujudkan hal ini, perlu diterapkan prinsip pendidikan berbasis kompetensi yang tidak hanya berorientasi pada bidang akademik atau vokasional semata, tetapi juga memberikan bekal learning how to learn sekaligus learning how to unlearn, tidak hanya belajar teori, tetapi juga mempraktekkannya untuk memecahkan problema kehidupan sehari-hari (Bently, 2000).

Perkembangan kehidupan di masyarakat menuntut diberlakukannya pendidikan secara lebih terstruktur yang memungkinkan dihasilkannya lulusan yang sesuai dengan kebutuhan di masyarakat tersebut. Aktivitas pembelajaran di sekolah sebagai wujud nyata penterjemahan sistem pendidikan di sekolah pada umumnya dan di kelas pada khususnya seharusnya tidak mengkotak-kotakan secara kaku berbagai bahan kajian melalui tiap

126 Jurnal PHENOMENON, Volume 1 Nomor 1, Juli 2011 
mata pelajaran. Hal ini dimaksudkan agar hasil belajar di sekolah terasakan manfaatnya baik bagi peserta didik langsung maupun bagi masyarakat seeara luas. Standar Kompetensi (SK) dan Kompetensi Dasar (KD) yang dituangkan di dalam standar isi untuk mata pelajaran yang terpisah-pisah sebaiknya dimaknai bahwa pencapaiannya dapat ditempuh melalui pengintegrasian SK dan KD beberapa mata pelajaran ke dalam satu wadah pembelajaran. Salah satu model pembelajaran yang bisa ditempuh adalah melalui model pembelajaran sains, lingkungan, teknologi dan masyarakat (SETS).

Perkembangan sains dan teknologi serta dampaknya pada lingkungan dan masyarakat, menjadi semakin tidak terpisahkan dalam kehidupan manusia. Mengingat keterkaitan yang sangat erat antara lingkungan, teknologi, dan masyarakat dengan sains, maka sangat dimungkinkan untuk menggunakan keterkaitan tersebut sebagai cara pandang atau visi kita dalam melihat sesuatu. Oleh karena itu meniadakan keterkaitan keempat unsur tersebut menjadi tidak relevan dalam konteks pendidikan masa kini. Untuk mewujudkan proses pembelajaran yang mengembangkan konsep sains, dengan memperhatikan penggunaanya pada teknologi, dan dampaknya bagi lingkungan dan masyarakat, maka dikembangkanlah pendekatan Science, Environment, Technology, and Society (SETS) sebagai pilihan dalam proses pembelajaran yang ada. Selain memberi peluang kepada peserta didik untuk belajar secara kontekstual, pendekatan ini juga memberi peluang dikembangkannya life skills pada diri peserta didik. Oleh karena itu, sangat relevan jika visi serta pendekatan SETS digunakan dalam pembelajaran di sekolah. (Binadja,2001).

Sebagai visi, secara sengaja kita membawa pemikiran para peserta didik tentang keberadaan keempat unsur (SETS) serta berbagai implikasi yang terkandung atau tercakup di dalamnya ketika mereka "melihat" sesuatu. Dari sana diharapkan peserta didik dapat menghasilkan pemikiran atau gagasan-gagasan baru (inovatif) yang dapat dihasilkan dari hasil "penglihatan" itu sesuai dengan

kemampuan mereka di jenjang usia atau jenjang pendidi- 
kan yang mereka lewati dengan memadukan berbagai macam pengalaman hidup mereka, sehingga kemampuan dan keberanian untuk menghadapi problema kehidupan, kemudian secara proaktif dan kreatif, mencari serta menemukan solusi untuk mengatasinya suatu permasalahannya.

\section{B. Dasar Pemikiran Pengembangan Kurikulum}

Negara Indonesia memiliki sumber daya alam yang sangat besar dan yang seharusnya dapat dinikmati dengan baik sepanjang hayat. Maka diperlukan adanya sumber daya manusia yang menguasai kemampuan fisik, intelektual, social dan kredibilitas sehingga mampu mengaplikasikan ilmu pengetahuannya untuk kesejahteraan hidup. Hal ini penting perlunya mutu lulusan yang memiliki kompetensi yang mampu menguasai ketrampilan dan kecakapan standar internasional. Perlunya pengembangan kurikulum yang mampu menjembatani dan melayani kebutuhan akan mutu lulusan sesuai dengan kebutuhan.

Pengembangan kurikulum adalah istilah yang komprehensif, didalamnya mencakup: perencanaan, penerapan dan evaluasi. Perencanaan kurikulum adalah langkah awal membangun kurikulum ketika pekerja kurikulum membuat keputusan dan mengambil tindakan untuk menghasilkan perencanaan yang akan digunakan oleh guru dan peserta didik. Penerapan Kurikulum atau biasa disebut juga implementasi kurikulum berusaha mentransfer perencanaan kurikulum ke dalam tindakan operasional. Evaluasi kurikulum merupakan tahap akhir dari pengembangan kurikulum untuk menentukan seberapa besar hasil-hasil pembelajaran, tingkat ketercapaian program-program yang telah direncanakan, dan hasil-hasil kurikulum itu sendiri. Dalam pengembangan kurikulum, tidak hanya melibatkan orang yang terkait langsung dengan dunia pendidikan saja, namun di dalamnya melibatkan banyak orang, seperti : politikus, pengusaha, orang tua peserta didik, serta unsur - unsur masyarakat lainnya yang merasa berkepentingan dengan pendidikan.

Prinsip-prinsip yang akan digunakan dalam kegiatan 
pengembangan kurikulum pada dasarnya merupakan kaidahkaidah atau hukum yang akan menjiwai suatu kurikulum. Dalam pengembangan kurikulum, dapat menggunakan prinsip-prinsip yang telah berkembang dalam kehidupan sehari-hari atau justru menciptakan sendiri prinsip-prinsip baru. Oleh karena itu, dalam implementasi kurikulum di suatu lembaga pendidikan sangat mungkin terjadi penggunaan prinsip-prinsip yang berbeda dengan kurikulum yang digunakan di lembaga pendidikan lainnya, sehingga akan ditemukan banyak sekali prinsip-prinsip yang digunakan dalam suatu pengembangan kurikulum. Dalam hal ini, Nana Syaodih Sukmadinata (1997) mengetengahkan prinsip-prinsip pengembangan kurikulum yang dibagi ke dalam dua kelompok : (1) prinsip - prinsip umum : relevansi, fleksibilitas, kontinuitas, praktis, dan efektivitas; (2) prinsipprinsip khusus : prinsip berkenaan dengan tujuan pendidikan, prinsip berkenaan dengan pemilihan isi pendidikan, prinsip berkenaan dengan pemilihan proses belajar mengajar, prinsip berkenaan dengan pemilihan media dan alat pelajaran, dan prinsip berkenaan dengan pemilihan kegiatan penilaian. Sedangkan Asep Herry Hernawan dkk (2002) mengemukakan lima prinsip dalam pengembangan kurikulum, yaitu :

1. Prinsip relevansi; secara internal bahwa kurikulum memiliki relevansi di antara komponen-komponen kurikulum (tujuan, bahan, strategi, organisasi dan evaluasi). Sedangkan secara eksternal bahwa komponen-komponen tersebutmemiliki relevansi dengan tuntutan ilmu pengetahuan dan teknologi (relevansi epistomologis), tuntutan dan potensi peserta didik (relevansi psikologis) serta tuntutan dan kebutuhan perkembangan masyarakat (relevansi sosilogis).

2. Prinsip fleksibilitas; dalam pengembangan kurikulum mengusahakan agar yang dihasilkan memiliki sifat luwes, lentur dan fleksibel dalam pelaksanaannya, memungkinkan terjadinya penyesuaian-penyesuaian berdasarkan situasi dan kondisi tempat dan waktu yang selalu berkembang, serta kemampuan dan latar bekang 
peserta didik.

3. Prinsip kontinuitas; yakni adanya kesinambungan dalam kurikulum, baik secara vertikal, maupun secara horizontal. Pengalaman-pengalaman belajar yang disediakan kurikulum harus memperhatikan kesinambungan, baik yang di dalam tingkat kelas, antar jenjang pendidikan, maupun antara jenjang pendidikan dengan jenis pekerjaan.

4. Prinsip efisiensi; yakni mengusahakan agar dalam pengembangan kurikulum dapat mendayagunakan waktu, biaya, dan sumber-sumber lain yang ada secara optimal, cermat dan tepat sehingga hasilnya memadai.

5. Prinsip efektivitas; yakni mengusahakan agar kegiatan pengembangan kurikulum mencapai tujuan tanpa kegiatan yang mubazir, baik secara kualitas maupun kuantitas.

Terkait dengan pengembangan Kurikulum Tingkat Satuan Pendidikan, terdapat sejumlah prinsip-prinsip yang harus dipenuhi, yaitu :

1. Berpusat pada potensi, perkembangan, kebutuhan, dan kepentingan peserta didik dan lingkungannya. Kurikulum dikembangkan berdasarkan prinsip bahwa peserta didik memiliki posisi sentral untuk mengembangkan kompetensinya agar menjadi manusia yang beriman dan bertakwa kepada Tuhan Yang Maha Esa, berakhlak mulia, sehat, berilmu, cakap, kreatif, mandiri dan menjadi warga negara yang demokratis serta bertanggung jawab. Untuk mendukung pencapaian tujuan tersebut pengembangan kompetensi peserta didik disesuaikan dengan potensi, perkembangan, kebutuhan, dan kepentingan peserta didik serta tuntutan lingkungan.

2. Kurikulum dikembangkan dengan memperhatikan keragaman karakteristik peserta didik, kondisi daerah, dan jenjang serta jenis pendidikan, tanpa membedakan agama, suku, budaya dan adat istiadat, serta status sos- 
ial ekonomi dan gender. Kurikulum meliputi substansi komponen muatan wajib kurikulum, muatan lokal, dan pengembangan diri secara terpadu, serta disusun dalam keterkaitan dan kesinambungan yang bermakna dan tepat antarsubstansi.

3. Tanggap terhadap perkembangan ilmu pengetahuan, teknologi, dan seni. Kurikulum dikembangkan atas dasar kesadaran bahwa ilmu pengetahuan, teknologi dan seni berkembang secara dinamis, dan oleh karena itu semangat dan isi kurikulum mendorong peserta didik untuk mengikuti dan memanfaatkan secara tepat perkembangan ilmu pengetahuan, teknologi, dan seni.

4. Relevan dengan kebutuhan kehidupan. Pengembangan kurikulum dilakukan dengan melibatkan pemangku kepentingan (stakeholders) untuk menjamin relevansi pendidikan dengan kebutuhan kehidupan, termasuk di dalamnya kehidupan kemasyarakatan, dunia usaha dan dunia kerja. Oleh karena itu, pengembangan keterampilan pribadi, keterampilan berpikir, keterampilan sosial, keterampilan akademik, dan keterampilan vokasional merupakan keniscayaan.

5. Menyeluruh dan berkesinambungan. Substansi kurikulum mencakup keseluruhan dimensi kompetensi, bidang kajian keilmuan dan mata pelajaran yang direncanakan dan disajikan secara berkesinambungan antarsemua jenjang pendidikan.

6. Belajar sepanjang hayat. Kurikulum diarahkan kepada proses pengembangan, pembudayaan dan pemberdayaan peserta didik yang berlangsung sepanjang hayat. Kurikulum mencerminkan keterkaitan antara unsurunsur pendidikan formal, nonformal dan informal, dengan memperhatikan kondisi dan tuntutan lingkungan yang selalu berkembang serta arah pengembangan manusia seutuhnya.

7. Seimbang antara kepentingan nasional dan kepentingan daerah. Kurikulum dikembangkan dengan memperha- 
tikan kepentingan nasional dan kepentingan daerah untuk membangun kehidupan bermasyarakat, berbangsa dan bernegara. Kepentingan nasional dan kepentingan daerah harus saling mengisi dan memberdayakan sejalan dengan motto Bhineka Tunggal Ika dalam kerangka Negara Kesatuan Republik Indonesia.

Pemenuhan prinsip-prinsip di atas itulah yang membedakan antara penerapan satu Kurikulum Tingkat Satuan Pendidikan dengan kurikulum sebelumnya, yang justru tampaknya sering kali terabaikan. Karena prinsip-prinsip itu boleh dikatakan sebagai ruh atau jiwanya kurikulum

Dalam mensikapi suatu perubahan kurikulum, banyak orang lebih terfokus hanya pada pemenuhan struktur kurikulum sebagai jasad dari kurikulum . Padahal jauh lebih penting adalah perubahan kutural (perilaku) guna memenuhi prinsipprinsip khusus yang terkandung dalam pengembangan kurikulum.

\section{SETS Dalam Kurikulum Tingkat Satuan Pendidikan}

Dalam kehidupan yang dikendalikan oleh teknologi serba digital, keterkaitan sains dan teknologi serta dampaknya pada lingkungan dan masayarakat perlu lebih ditekankan pada tiap sudut pembelajaran. Pendidikan bervisi SETS tidak hanya memperhatikan isu dan masyarakat serta lingkunngan, namun lebih menitikberatkan cara melakukan sesuatu untuk kepentingan masyarakat serta kelestarian terjaga sementara kepentingan lain terpenuhi. Dalam membuat konsep sains berguna dalam teknologi untuk memenuhi keperluan masyarakat, yang berakibat pada permasalahan lingkungan. Pengajaran SETS atau Salingtemas membantu siswa untuk mengetahui sains, perkembangannya dan bagaimana perkembangan sains dapat mempengaruhi lingkungan, teknologi, dan masyarakat secara timbal balik (Binadja,2006). Visi SETS merupakan cara pandang yang memungkinkan kita untuk melihat, bahwa di dalam sesuatu yang kita kenal, terdapat saling keterkaitan antara konsep-kon- 
sep sains, lingkungan, teknologi, dan masyarakat, sebagai satu kesatuan yang integratif.

Pendidikan bervisi SETS memberi peluang siswa untuk berpikir komperhensif dengan mengintegrasikan berbagai pengetahuan yang telah dimiliki (Binadja,2000). Tujuan pembelajaran berwawasan SETS baru dapat tercapai saat guru dan siswa berperan bersama didalamnya (Binadja, 2001). Guru harus dapat mencari informasi / berita yang berkembang di masyarakat untuk diangkat pada saat membahas materi yang berkaitan. Binadja (2001) menyebutkan contoh ciri pembelajaran berpendekatan SETS pada mata pelajaran biologi antara lain :

1. Memberi pembelajaran konsep Biologi yang diinginkan

2. Murid diajak melihat teknologi berkaitan konsep yang dipelajari serta memanfaatkan konsep Biologi ke bentuk teknologi untuk kepentingan masyarakat.

3. Murid diminta berpikir tentang berbagai kemungkinan akibat (positif/negatif) yang dapat terjadi dalam proses pentransferan Biologi ke dalam bentuk teknologi.

4. Murid diminta menjelaskan keterkaitan unsur sains yang diperbincangkan dengan unsur lain dalam SETS yang saling mempengaruhi.

5. Murid diajak mempertimbangkan manfaat/kerugian penggunaan konsep sains Biologi tersebut bila diubah dalam bentuk teknologi.

6. Murid diajak mencari alternatif pengentasan terhadap kerugian yang mungkin timbul oleh penerapan sains ke bentuk teknologi terhadap lingkungan dan masyarakat (mencari bentuk teknologi yang lebih baik).

Dalam konteks konstruktivisme, murid diajak berbincang tentang SETS berkaitan dengan konsep sains yang dibelajarkan dari berbagai macam arah dan berbagai macam titik awal tergantung pengetahuan dasar yang dimiliki oleh siswa. Menurut Nurwati (2000), pendekatan SETS dalam pembelajaran Biologi akan memotivasi siswa menjadi lebih tertarik terhadap bahasan yang sedang dipelajarinya karena dikaitkan dengan hal nyata 
yang terjadi dalam kehidupan sehari-hari.

\section{Kurikulum Tingkat Satuan Pendidikan dan Ketrampilan Hidup}

Ketrampilan hidup, dapat ditumbuhkan melalui pengembangan kurikulum, salah satu tujuan pendidikan nasional adalah agar lulusan memiliki keunggulan kompetitif dan komparatif sesuai dengan standar mutu kelulusan, baik nasional maupun internasional. Kompetensi yang tercantum dalam kurikulum tingkat satuan pendidikan yang tertera dalam setiap silabus mata pelajaran menjamin tumbuhnya keimanan dan ketakwaan terhadap Tuhan Yang Maha Esa, yang meliputi penguasaan ketrampilan hidup, baik akademik, sosial, serta pengembangan kepribadian. Dari pejabaran tiap standar kompetensi menjadi kompetensi dasar yang tercapai melalui setiap indikatornya. Dari tiap indikator inilah proses pemantauan tercapainya kecakapan hidup terevaluasi, karena pengukuran indikator melalui kata kerja operasional yang dapat teramati dan terukur. Contoh konkrit, siswa dapat menganalisa, menjelaskan, mendiskusikan, mempraktekkan, melaksanakan. Dalam tiap kondisi seperti inilah kompetensi yang beintegrasi dengan life skil/kecakapan hidup terukur.

\section{E. Kesimpulan}

Dari pembahasan di atas dapat di simpulkan :

1. Kompetensi dalam kurikulum tingkat satuan pendidikan dapat tercapai asalkan ada kejelasan dengan memperhatikan keutuhan dan keterintegrasian pengetahuan yang mencukupi sesua tujuan yang dikehendaki.

2. Dalam pengembangan kompetensi menjadi silabus perlu penekanan tujuan di setiap indikatornya, sehingga integrasi life skill apa yang ingin di capai dapat terukur jelas.

3. Untuk memudahkan pencapaian unsur SETS, pengintegrasian pada setiap materi pokok secara utuh.

4. Pelaksanaan pembelajaran dalam pengintegrasian ini tidak harus secara konvensional. 


\section{DAFTAR PUSTAKA}

Binadja, Achmad (2001) Pendidikan Berwawasan SETS (Sciense, Environment,Technology, and Society) Dalam Managemen Pendidikan Berbasis Sekolah, Makalah disajikan dalam seminar, Guntur, Purwodadi 22 November 2000.

Binadja, Achmad (2002). Pendidikan Bervisi SETS (Science, Environment, Technology and Society) Implikasi Kurikulum Berbasis Kompetensi Pada Pendidikan Dasar dan Menengah. Makalah Seminar Nasional Pendidikan Berbasis Kompetensi UNNES Semarang 27 Februari 2002.

Puskur, Balitbang,Depdiknas (2002) Kurikulum Berbasis Kompetensi.

Listyono, (2003) Model Pembelajaran Penemuan Konsep Dalam Meningkatkan Aktifitas Dengan Pendekatan SETS bervisi Qur'an dan Hadist.

Swara Ditpertais: No. 17 Th. II, 18 Oktober 2004, Pengembangan Kurikulum Berbasis Kompetensi

I Made Alit Mariana,Eddy Hidayat (2000). Hakekat Pendekatan SETS dalam Pembelajaran Sains. Bandung : PPG IPA.

Nicholas, J (19995). Learning And Skills. London and New York : Longman.

Novak,D. And Gowin (1986). Learning How To Learn. Sydney : Departement of Education New York State College of Agriculture and Life Sciences Cornell University. 